\title{
Effects of alfalfa chaff on the gastric mucosa in adult horses
}

\author{
Sarah Vondran', Monica Venner², Manfred Coenen' and Ingrid Vervuert' \\ ${ }^{1}$ Institut für Tierernährung, Ernährungsschäden und Diätetik, Veterinärmedizinische Fakultät, Universität Leipzig, Deutschland \\ 2 Tierärztliche Klinik für Pferde, Destedt, Deutschland
}

\begin{abstract}
Summary: Feeding alfalfa hay is often recommended because of its buffering properties associated with substances, like protein and calcium, to prevent lesions. However, the particle size of the alfalfa preparations seems to have an influence on gastric mucosa in weanlings. We hypothesized that feeding alfalfa chaff with harsh particles would negatively impact glandular gastric mucosa in adult horses under maintenance conditions. The study was performed as a cross-over $2 \times 2$ Latin square design with 16 -days washout intervals over 8 weeks. Six geldings (19 to 21 years of age) were kept in individual boxes $\left(10.85 \mathrm{~m}^{2}\right)$. The horses were fed $1.5 \mathrm{~kg}$ per $100 \mathrm{~kg}$ BW of alfalfa chaff or grass hay, offered twice a day. Horses were subjected to a gastroscopy immediately before the feeding period $(T=0)$, after the first feeding period of 12 days $(T=12)$, after the first washout period $(T=28)$, after the second feeding period of 12 days $(T=40)$ and after the second washout period $(T=56)$. When horses were fed alfalfa chaff the median score of the antrum raised from 0 to 2 ( $p=0.07)$. And after the washout period the median score of the antrum decreased to $0.5(p=0.04)$. In conclusion feeding alfalfa chaff induced glandular mucosal lesions at the antrum. Lesions of the antrum induced by feeding alfalfa chaff seem to be reversible and to heal within 16 days.
\end{abstract}

Keywords: alfalfa, particle size, gastric lesions, gastroscopy, EGGD, nutrition

Citation: Vondran S., Venner M. , Coenen M., Vervuert I. (2017) Effects of alfalfa chaff on the gastric mucosa in adult horses. Pferdeheilkunde 33, 66-71; DOI 10.21836/PEM20170109

Correspondence: PD Dr. med. vet. Ingrid Vervuert, Institute of Animal Nutrition, Nutrition Diseases, Faculty of Veterinary Medicine, University of Leipzig, Germany; e-mail: Ingrid.Vervuert@vetmed.uni-leipzig.de

\section{Introduction}

Alfalfa hay is a suitable forage for horses. It has been shown to be a better source of nutrients for horses than grass hay. Alfalfa contains readily available calcium and protein and can thus be used to upgrade poor quality roughages. Because of its good source of digestible nutrients, there are therapeutic applications for horses with electrolyte imbalances, hoof horn problems, old horses and horses with gastric ulceration (Cuddeford 1994). For example, Nadeav et al. (2000) found a lower incidence of squamous mucosal lesions feeding an alfalfa hay diet than feeding a brome hay diet in horses. A diet of alfalfa hay significantly improved healing of squamous mucosal lesions in this particular study.

However, particle size of alfalfa chaff preparations seemed to have detrimental effects on glandular gastric mucosa in horses. In foals, feeding alfalfa chaff resulted in glandular mucosa lesions at the pylorus (Fedtke et al. 2015). The authors suggested the lesions to be related to mechanical irritation by the fine particles similar to findings in swine. In the study performed by Mößeler et al. (2012) only the score of squamous gastric ulcers was significantly higher feeding pigs a finely ground pelleted diet, but not the score of the glandular mucosa as seen in horses. Conversely, feeding a coarse ground feed reduced mucosal lesions of the squamous mucosa in growing pigs (Millet et al. 2012). Recently, we found significant higher lesion scores when feeding alfalfa chaff to weanlings, particularly at the pylorus than when feeding grass hay (Vondran et al. 2016). As about $91 \%$ of the particles of the alfalfa chaff were sized over $2 \mathrm{~mm}$, we hypothesized that the harsh, acanthous structure of alfalfa chaff may cause mechanical irritation at the pylorus. But it remai- ned unclear whether the mechanical injury could be only observed in weanlings during the stressful weaning process as a result of an impaired mucosal defense or whether the mechanical injury could be also induced in adult horses under maintenance conditions.

The aim of this study was to investigate the effects of feeding alfalfa chaff with a high amount of particles longer than 2 $\mathrm{mm}$ on gastric mucosa in adult horses. We hypothesized that feeding a high proportion of long, harsh particles (alfalfa chaff) would impact gastric mucosa of the pylorus in horses under maintenance conditions, similar to the results obtained in weanlings. We used alfalfa chaff as this is the common alfalfa preparation used in equine complementary feed. Further we hypothesized that these pyloric lesions are reversible and might heal during the 16-d lasting washout periods on pasture.

\section{Material and methods}

Animals

Two Standardbred geldings and four Warmblood geldings, 19 to 21 years of age, with a mean BW $( \pm S D)$ of $614 \pm 31$ $\mathrm{kg}$ were included in the study. Inclusion criteria for the horses were: absence of pre-existing diseases including teeth problems, no severe findings at the first gastroscopy (means no gastric lesion score $>2$ ) and no medication 3 months prior to initiation of the study. The geldings were allocated to each group according to the homogenous distribution of gastric findings at the first gastroscopy. All horses stayed on the teaching farm of the Faculty of Veterinary Medicine nearby Leip- 
zig, Germany. Horses were fed and kept under same maintenance conditions. They were kept together on the same pasture for the last four months prior to the study with free access to water and a shelter barn with straw bedding.

During the study horses were kept in individual boxes $\left(10.85 \mathrm{~m}^{2}\right)$ that allowed social contacts. Ground of the boxes was covered with rubber mats and straw bedding. Horses had access to a sand paddock for at least 3 hours twice every day. During the study all horses had free access to water. The geldings were monitored four times daily by a veterinarian for signs of discomfort, depression, inappetence, bruxism, or colic.

\section{Feeding}

A cross-over design ( $2 \times 2$ Latin square) was used to compare the effects of feeding either alfalfa chaff or grass hay on the gastric mucosa with horses randomly assigned to consume one of the test diets for 12 days. 1. Alfalfa chaff: Each horse was fed $1.5 \mathrm{~kg}$ of unsieved alfalfa chaff per $100 \mathrm{~kg}$ BW daily. 2. Hay: Each horse was fed $1.5 \mathrm{~kg}$ of grass hay per $100 \mathrm{~kg}$ BW daily. The feed was offered in two equal portions twice a day (7:00 am and 8:00 pm). Feed intake was monitored several times daily and leftovers were reweighed after 24 hours. In total, the different diets were fed for 12 days to each horse. Each feeding period was followed by a washout period for 16 days. During the washout period horses had access to pasture for 24 hours.

\section{Gastroscopy}

A gastroscopy with a flexible gastroscope (Karl Storz, Tuttlingen, Germany), working length $3 \mathrm{~m}$, was performed immediately prior to the feeding $(T=0)$ and again after the feeding period of 12 days $(T=12)$, after 16 days on pasture $(T=28)$, after the second feeding period of 12 days $(T=40)$ and for a last time after the second washout period of 16 days $(T=56)$. Prior to gastroscopy horses were fasted by using boxes with rubber mats for 12 hours. Water was provided ad libitum. The horses were sedated with $0.02 \mathrm{mg}$ per $\mathrm{kg} \mathrm{BW}$ iv detomidinhydrochloride (Cepesedan ${ }^{\circledR}$; CP Pharma, Burgdorf, Germany). The stomach was insufflated with air until the mucosal folds vanished. The following regions of the stomach were evaluated separately: dorsal squamous fundus; lesser curvature; greater curvature of the squamous region; greater curvature of the glandular region; antrum; and pylorus. Each region and mucosal type was given a score from 0 to 4 . Squamous mucosa was scored according to a proposal of the European College of Equine Internal Medicine (Sykes et al.
2015) (Table 1). Glandular gastric mucosa including the antrum and pylorus was evaluated according to a modified scoring system (Table 2). Gastric mucosa was evaluated during gastroscopy by the same blinded and experienced investigator.

\section{Scaling}

Body weight was measured by an electronic weight scale (Texas Trading, Oamaru, New Zealand) immediately before each gastroscopy.

Feedstuffs were weighed using an automatic scale (MettlerToledo GmbH, Albstadt, Germany).

\section{Nutrient analysis}

Dry matter (DM) was determined after oven-drying $\left(103^{\circ} \mathrm{C}\right)$ to a constant mass (Table 3). Crude ash was measured by ashing the feeds in a muffle furnace $\left(6 \mathrm{~h}, 600^{\circ} \mathrm{C}\right.$ ) (Naumann and Bassler 1976). Starch content was estimated polarimetrically (Polartronic E, Schmidt and Haensch, Berlin, Germany). Sugar contents (glucose and sucrose) were determined by the Luff Schoorl method. Crude nutrients were assayed by the Weende system (van Soest 1991). Neutral detergent fiber was analyzed by the Fibertec ${ }^{\circledR}$ (Tectator, Rellingen, Germany) (van Soest 1991). Salicylic acid concentrations of the grass hay and the alfalfa chaff were measured by high performance liquid chromatography and mass spectrometry (Table 4). The grass hay and alfalfa chaff were additionally analyzed for microbial counts using a conventionael plate system. Furthermore, the grass hay was analyzed for botanical composition. According to the botanical composition the grass hay consisted of Dactylis glomerata, Poa pratensis, Agrostis stolonifera, Anthoxanthum odoratum and Bromus hordeaceus.

\begin{tabular}{|c|c|}
\hline \multicolumn{2}{|c|}{$\begin{array}{l}\text { Table } 1 \text { Scoring system of the squamous regions of the equine } \\
\text { stomach, adapted from the proposal of the European College of } \\
\text { Equine Internal Medicine (Sykes et al. 2015). I Beurteilungsgrade } \\
\text { der kutanen Schleimhaut des Pferdemagens, nach den Vorschlägen } \\
\text { des European College of Equine Internal Medicine (Sykes et al. } \\
\text { 2015) }\end{array}$} \\
\hline Grade & Characteristics \\
\hline 0 & Epithelium intact and no appearance hyperkeratosis \\
\hline 1 & Mucosa intact, but areas of hyperkeratosis \\
\hline 2 & Small, single or multifocal lesions \\
\hline 3 & Large single or extensive superficial lesions \\
\hline 4 & Extensive lesions with areas of apparent deep ulceration \\
\hline
\end{tabular}

Table 2 Scoring system of the glandular regions including the antrum and pylorus of the equine stomach. / Beurteilungsgrade der glandulären Region einschließlich Antrum pyloricum und Pylorus des Pferdemagens

\begin{tabular}{cl}
\hline Grade & Characteristics \\
\hline 0 & Epithelium intact and no appearance of hyperemia (reddening) or fibrinosupperative areas \\
1 & Intact flat mucosa, but with small single or multifocal areas of reddening \\
2 & Raised mucosa with large single or multifocal areas of reddening or fibrinosupperative areas, no signs of bleeding \\
3 & Ridged or depressed mucosa with severe signs of bleeding or with large and distinct fibrinosupperative areas \\
4 &
\end{tabular}


Sieving

To determine particle sizes $50 \mathrm{~g}$ of dry alfalfa chaff were sieved for 5 minutes with an excursion of $1 \mathrm{~mm}$. Size of the sieves were $2 \mathrm{~mm}, 1 \mathrm{~mm}, 0.5 \mathrm{~mm}$ and $0.25 \mathrm{~mm}$. Results of sieving are shown in Table 5.

\section{Statistical analysis}

Statistical analysis was performed using a statistical software program (STATISTIKA, StatSoft). Body weight was analyzed for normal distribution by the Shapiro-Wilk W test. Stomach scores were calculated using medians, 25 th and 75 th percentiles, and ranges. The Wilcoxon signed rank test was used to compare gastroscopic scores between the two feeding protocols. Friedmans ANOVA was performed to compare the gastroscopic findings for the different time points within the feeding protocols. A value of $p<0.05$ was considered significant.

\section{Results}

Mean body weight $( \pm \mathrm{SD}$ ) prior to the study was $621 \pm 25.5 \mathrm{~kg}$ and it was constant during the whole period of the study. None of the horses in the study demonstrated any clinical signs commonly associated with the presence of gastric ulcers such as colic, inappetence, or depression, as reviewed by Andrews et al. (1999).

Table 3 Chemical composition of the feedstuffs (expressed as $\mathrm{g}$ per kg dry matter). I Chemische Zusammensetzung der Futtermittel (Angaben g pro kg Futtermittel)

\begin{tabular}{cccc}
\hline \multicolumn{2}{c}{ Nutrient } & Alfalfa chaff & Hay \\
\hline Crude ash & g/kg DM & 71 & 53 \\
Crude protein & $\mathrm{g} / \mathrm{kg} \mathrm{DM}$ & 150 & 83 \\
Crude fibre & $\mathrm{g} / \mathrm{kg} \mathrm{DM}$ & 412 & 325 \\
$\mathrm{NDF}$ & $\mathrm{g} / \mathrm{kg} \mathrm{DM}$ & 578 & 643 \\
$\mathrm{Ca}$ & $\mathrm{g} / \mathrm{kg} \mathrm{DM}$ & 12.3 & 4.7 \\
$\mathrm{P}$ & $\mathrm{g} / \mathrm{kg} \mathrm{DM}$ & 2.74 & 1.7 \\
$\mathrm{Mg}$ & $\mathrm{g} / \mathrm{kg} \mathrm{DM}$ & 1.65 & 1.5 \\
\hline
\end{tabular}

JM: dry matter, NDF = neutral detergent fiber, $\mathrm{Ca}=$ Calcium, $\mathrm{P}=$ Phosphor, $\mathrm{Mg}=$ Magnesium, DM: Trockensubstanz, NDF = Neutrale Detergens-Faser,

$\mathrm{Za}=$ Calcium, $\mathrm{P}=$ Phosphor, $\mathrm{Mg}=$ Magnesium

Table 4 Concentration of salicylic acid in hay or alfalfa chaff (expressed as $\mathrm{mg} / \mathrm{kg}$ feedstuff) | Konzentration der Salicylsäure in Heu oder Luzernehäcksel (Angabe in mg/kg Futtermittel)

\begin{tabular}{ccc}
\hline Diet & & Salicylic acid \\
\hline Hay & $\mathrm{mg} / \mathrm{kg}$ & 13.1 \\
Alfalfa chaff & $\mathrm{mg} / \mathrm{kg}$ & 15.5 \\
\hline
\end{tabular}

Mycological examination of the hay showed $1 \times 10^{6}$ cfu of yeast. Analysis of the alfalfa chaff did not show any important results. Salicylic acid concentrations of the grass hay were $13.1 \mathrm{mg} / \mathrm{kg}$ and of the alfalfa chaff $15.5 \mathrm{mg} / \mathrm{kg}$ (Table 4).

Median lesion score (in brackets 25/75 percentile) of the greater curvature of the squamous mucosa prior to feeding hay was $0.5(0 / 1)$ (Figure 1). After feeding hay median score of this region decreased to $0(0 / 0)(p=0.11)$. There was no change of the median score during the washout period after feeding hay $(0 / 1)$. Median lesion score of the greater curvature of the squamous mucosa was $1.5(0 / 2)$ prior to feeding alfalfa chaff (Figure 1). After feeding alfalfa chaff median score of this region decreased to $0(0 / 1)(p=0.07)$. There was no change of the score of the greater curvature of the squamous mucosa during the washout period after feeding alfalfa chaff $(0 / 1)$ (Figure 1).

Median lesion score of the lesser curvature of the squamous mucosa prior to feeding hay was $1.5(1 / 2)$ (Figure 2). After feeding hay the median score decreased to $0(0 / 1)(p=0.03)$ (Figure 2). After the washout period median score increased to $0.5(0 / 2) \quad(p=0.27)$, when horses were fed hay before (Figure 2). Median lesion score of the lesser curvature was 1 prior to feeding alfalfa chaff. After feeding alfalfa chaff the median score was $0.5(0 / 2)(p=0.72)$. After the washout period median score increased to $1.5(1 / 2)(p=0.27)$, when horses were fed alfalfa chaff before (Figure 2).

Median lesion score of the antrum prior to feeding hay was 0 $(0 / 1)$ (Figure 3). After feeding hay the median score of the antrum increased to $1(0 / 1)(p=0.11)$ (Figure 3). After the washout period median score decreased to $0(0 / 2)$ $(p=0.72)$, when horses were fed hay before. Median lesion score of the antrum was $0(0 / 0)$ prior to feeding alfalfa chaff. After feeding alfalfa chaff the median score increased to 2 $(2 / 2)(p=0.07)$. After the washout period median score of

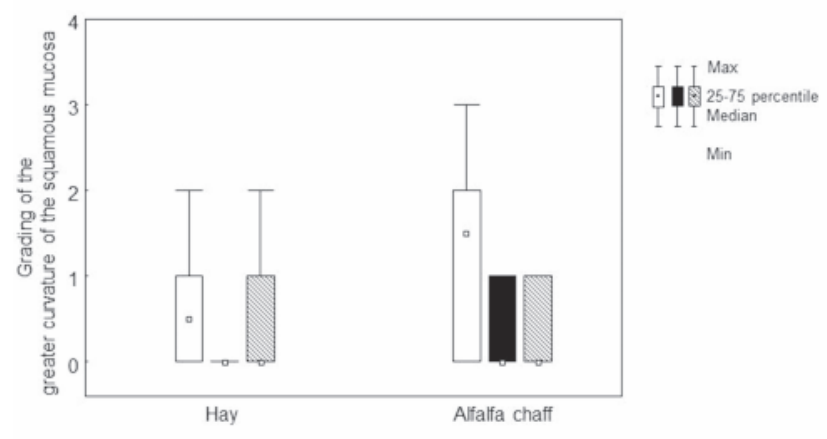

Fig. 1 Mucosa lesion grades for the greater curvature of the squamous mucosa before and after feeding for the different feeding protocols (white plots before feeding; black plots after feeding; grey plots after washout). I Magenschleimhaut-Score an der großen Kurvatur der kutanen Schleimhaut vor und nach der Fütterung der verschiedenen Rationen (weiße Balken für Ergebnisse vor der Fütterung; schwarze Balken für Ergebnisse nach der Fütterung; grave Balken für Ergebnisse nach der Washout-Periode)

Table 5 Percentages of different particle sizes of alfalfa chaff. / Verteilung der Partikelgrößen der Luzernehäcksel angegeben in Prozent

\begin{tabular}{|c|c|c|c|c|c|}
\hline Diet & $>2 \mathrm{~mm}$ & $>1 \mathrm{~mm}$ & $>0.5 \mathrm{~mm}$ & $>0.25 \mathrm{~mm}$ & $<0.25 \mathrm{~mm}$ \\
\hline Alfalfa chaff & $94.69 \%$ & $3.77 \%$ & $0.84 \%$ & $0.12 \%$ & $0.01 \%$ \\
\hline
\end{tabular}


the antrum decreased to $0.5(0 / 1)(p=0.04)$, when horses were fed alfalfa chaff before (Figure 3).

No gastric mucosa lesions were found at the greater curvature of the glandular region and of the pylorus during the study.

\section{Discussion}

Alfalfa hay is believed to have beneficial effects on gastric mucosa by buffering gastric $\mathrm{pH}$, as it contains large amounts of calcium, magnesium and protein. Alfalfa hay contains calcium between $15-26.3 \mathrm{~g} / \mathrm{kg}$ dry matter (Cuddeford 1994). A high intake of calcium reduced the basal $\mathrm{HCl}$ secretion in rats (Fisher et al. 1990). This effect was supposed to be a result of higher extra- and intracellular calcium concentrations in parietal and G-cells. Higher extra- and intracellular calcium concentrations may lower the CAMP concentration, thus redu-

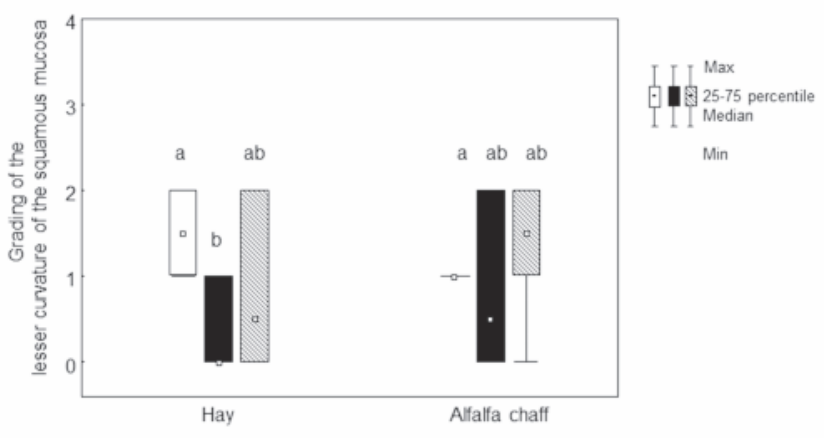

Fig. 2 Mucosa lesion grades for the lesser curvature of the squamous mucosa before and after weaning for the different feeding protocols (white plots before feeding; black plots after feeding; grey plots after washout). Unlike letters indicate a significant difference with $\mathrm{p}<0.05$. I Magenschleimhaut-Score an der kleinen Kurvatur der kutanen Schleimhaut vor und nach der Fütterung der verschiedenen Rationen (weiße Balken für Ergebnisse vor der Fütterung; schwarze Balken für Ergebnisse nach der Fütterung; grave Balken für Ergebnisse nach der Washout-Periode). Kleine Buchstaben stehen für signifikante Unterschiede mit einem $p$-Wert von <0,05.

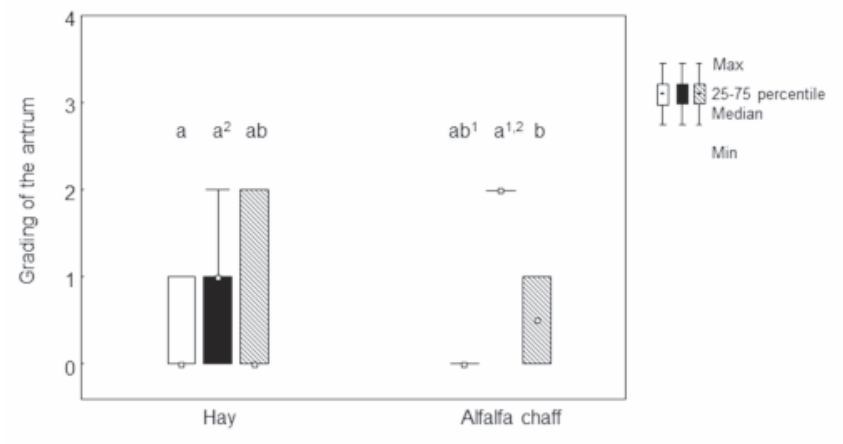

Fig. 3 Mucosa lesion grades for the antrum before and after weaning for the different feeding protocols (white plots before feeding; black plots after feeding; grey plots after washout). Unlike letters indicate a significant difference with $p<0.05$. I Magenschleimhaut-Score am Antrum pyloricum vor und nach der Fütterung der verschiedenen Rationen (weiße Balken für Ergebnisse vor der Fütterung; schwarze Balken für Ergebnisse nach der Fütterung; grave Balken für Ergebnisse nach der Washout-Periode). Kleine Buchstaben stehen für signifikante Unterschiede mit einem $p$-Wert von $<0,05$. cing the production of $\mathrm{HCl}$ (Fisher et al. 1990). Exposure of the equine gastric mucosa to $\mathrm{HCl}$ and short chain fatty acids (SCFAs) decreased sodium transport of the cells significantly. As sodium transport is a value for cell vitality, exposure to $\mathrm{HCl}$ seems to cause cell damage. After the addition of calcium carbonate the decreased values of sodium transport returned to values that were measured before the negative effects of $\mathrm{HCl}$ and short chain fatty acids took part (Andrews et al. 2006). From these results, the authors proposed that calcium has a protective effect in the development of squamous gastric lesions. Under practical feeding conditions, Nadeau et al. (2000) found significantly lower scores of squamous gastric lesions in horses fed an alfalfa hay/grain diet compared to horses fed a brome hay diet. The authors concluded high amounts of protein and the quality of protein itself may have buffering effects in the stomach as previously seen in cattle (Haaland et al. 1982). This could be the reason, why in our study lesion scores of the greater curvature of the squamous mucosa decreased after feeding alfalfa chaff. However, due to the low number of horses, results failed to get significant $(p=0.07)$. In contrast to Nadeau et al. (2000), recent studies have shown an impact of the particle size of alfalfa on the gastric mucosa in foals. In the study performed by Fedtke et al. (2015), weanlings fed alfalfa chaff had severe lesions at the pylorus after the weaning process. The authors speculated that the gastric lesions of the pylorus might be related to the small particles of the alfalfa chaff similar to results obtained in swine.

In a study performed by Mößeler et al. (2010) the gastric ulcer scores were significantly higher in pigs fed a finely ground pelleted diet, than those fed a diet of larger particle size. Furthermore, feeding a coarse ground feed reduced mucosa lesions of the pars oesophagea in growing pigs (Millet et al. 1990). In accordance to the results from Fedtke et al. (2015) and the present findings, Vondran et al. (2016) observed higher lesion scores at the pylorus in weanlings fed alfalfa chaff ( $91 \%$ of particles over $2 \mathrm{~mm}$ ) than in weanlings fed alfalfa pellets $(60 \%$ of particles under $0.25 \mathrm{~mm}$ ). In the study from Vondran et al. (2016) the nutrient intake such as protein and calcium were similar between the different diets in the weanlings. In consequence, any positive or negative effects from nutrients can be excluded. Therefore, authors hypothesised that the harsh, acanthous structure of alfalfa chaff may cause mechanical injury at the pylorus in weanlings and not the small particles as seen in swine. In addition, the stressful conditions of the weaning process might have impaired the gastric mucosa and it might have become more vulnerable and susceptible for ulcers. Until now, the effect of particle size of alfalfa chaff was only examined in foals by using the weaning procedure as a model to induce gastric lesions. It remained unclear whether the mucosa injuries can be only observed in weanlings during the stressful weaning process as a result of an impaired mucosal defence or whether the damages can be also induced in adult horses under maintenance conditions. In consequence, our study was performed in adult horses under maintenance conditions without any harmful factors which may have an impact to induce gastric ulcers such as weaning, medication, fasting, high grain intake or others. The results of the recent study are in accordance to the results already seen in weanlings. Similar to the results obtained in weanlings (Fedtke et al. 2015, Vondran et al. 2016), adult horses under maintenance conditions fed alfalfa chaff showed numerical more and severe 
lesions at the antrum than horses fed grass hay. After feeding alfalfa chaff the median score of the antrum raised from 0 to $2(p=0.07)$. Due to the low number of horses, results failed to get significant. Salicylic acid belongs to the pharmacological group of non-steroidal antiphlogistics. While inhibiting cyclooxigenase I, the protective effects of prostaglandine (for example vasodilatation and production of mucin) to the glandular gastric mucosa are stopped and peptic ulcers may develop (MacAllister et al. 1993). A high salicylate concentration which is well known as an antinutrional factor in alfalfa (Beaumier et al. 1983) can be excluded as a reason for gastric lesions in our study, as we found similar concentrations in hay and alfalfa chaff (supplementary file 1). The antrum is an area of the stomach with high motility. The movement of the alfalfa stems may excoriate the mucosa during the antrum passage. Due to initial injury the glandular mucosa of the antrum might become more vulnerable to SCFA, hydrogenic acid and/or bile salts. Nevertheless feeding alfalfa chaff seems to have various effects on the glandular and squamous regions of the stomach. Median lesion scores of the greater and lesser curvature of the squamous mucosa decreased after feeding alfalfa chaff although grass hay feeding revealed the same findings. In conclusion, feeding alfalfa chaff does not have outstanding positive effects on gastric mucosa, but may induce mucosa damages around the antrum pyloricum in adult horses.

The second aim of this study was to investigate, if the gastric mucosa lesions caused by feeding alfalfa chaff are reversible. Therefore horses spent 16 days on pasture after the feeding periods. The degree and the time for healing of gastric lesions depend on the size and mainly on the depth of the lesion (Bell et al. 2007). Superficial lesions of the squamous mucosa might heal in about 7 days; deep ulcerations at the glandular mucosa might need 3 month for healing (Murray 1997). Lesion healing in the equine gastric squamous mucosa appears to be an interrelated and dynamic process. Healing of erosions or ulcers starts with epithelial hyperplasia accompanied by congestion and proliferation of capillaries (angiogenesis) in the lamina propria (Murray 1999). Angiogenesis has been shown to be pivotal for healing of duodenal ulcers in rats (Szabo et al. 1994). When horses spent 16 days on pasture after being fed alfalfa chaff, median lesion score of the antrum decreased from 2 to 0.5. According to our results, mild lesions of the glandular region caused by mechanical irritation of alfalfa chaff might heal during 16 days on pasture rest without any medical treatment.

In summary, the gastric mucosa of the horse seems to be very susceptible to lesions. Even the change from pasture to box stabling with hay diet might cause lesions as shown in the present study. In our study alfalfa chaff induced lesions of the antrum in adult horses under maintenance conditions. But the effects of feeding alfalfa chaff varied for the different regions of the stomach. Alfalfa chaff might cause mechanical irritation at the glandular mucosa of the antrum, but seem to have positive effects on the squamous mucosa although grass hay feeding has the same potential considering squamous mucosa. Mild gastric lesions of the antrum caused by feeding alfalfa chaff might heal in 16 days with pasture access for $24 \mathrm{~h}$ a day. It remains open whether the mucosal injuries of the antrum can be only observed in feeding alfalfa chaff or even when alfalfa hay is fed. For practical feeding advice a traditional hay ration in sufficient amounts (minimum 1.5\% of BW daily) is recommended.

\section{Acknowledgment}

We acknowledge Prof. Dr. M. Kietzmann (Department of Pharmacology, Veterinary School, Hanover, Germany) for the analysis of the salicylic acid concentrations of the grass hay and alfalfa chaff.

\section{Conflict of interest statement}

The authors exclude any conflict of interest regarding technical devices of drugs used in this study.

\section{Animal Welfare Statement}

The project was approved by the Ethics Committee for Animal Rights Protection of the District Government in Leipzig, in Saxony (TW 18/15, LDD24-5131/331/21), in accordance with German legislation for animal rights and welfare.

\section{References}

Andrews F. M., Bernard, W. Byars D., Cohen N., Divers T., MacAllister C., Mc Gladdery A., Merritt A., Murray M., Orsini J., Snyder J., Vatistas N. (1999) Recommendations for the diagnosis and treatment of equine gastric ulcer syndrome (EGUS): The Equine Gastric Ulcer Council. Equine Vet. Educ. 1 1, 262-272

Andrews F. M., Buchanan B. R., Smith S. H., Elliott S. B. und Saxton A. M. (2006) In vitro effects of hydrochloric acid and various concentrations of acetic, propionic, butyric, or valeric acids on bioelectric properties of equine gastric squamous mucosa. Am. J. Vet. Res. 67, 1873-1882

Beaumier P., Fenwick J., Young L., Hazen S., Hama K., Laviolette B., Deocampo Z., Park H., Sio N., Timmings S., Todi F. (1983) Salicylic acid in the horse: Studies conducted for agriculture Canada by the Canadian race testing laboratories. Proceedings 5th Int Conference on control of the use of drugs in racehorses, Toronto

Bell R. J. W., Mogg T. D., Kingston J. K. (2007) Equine gastric ulcer syndrome in adult horses: A review. New Zeal. Vet. J. 55, 1-12

Cuddeford D. (1994) Artificially dehydrated lucerne for horses. Vet. Rec. 29, 426-429

Fedtke A., Pfaff M., Volquardsen J., Venner M. und Vervuert I. (2015) Effects of feeding different roughage-based diets on gastric mucosa after weaning in warmblood foals. Pferdedheilkunde 31, 596-602

Fisher H., Kaufman R. H., Hsu H. C., Kasziba E., Farmanfarmaian A., Flancbaum L. J. (1990) Inhibition of gastric acid secretion in the rat by high calcium. Nutrit. Res. 10, 1441-1453

Haaland G., Tyrrell H., Moe P., Wheeler W. (1982) Effect of crude protein level and limestone buffer in diets fed at two levels of intake on rumen $\mathrm{pH}$, ammonia-nitrogen, buffering capacity and volatile fatty acid concentration in cattle. Anim. Sci. 55, 943-950

MacAllister C. G., Morgan S. J., Borne T., Pollet R. A. (1993) Comparison of adverse effetcs of phenylbutazone, flunixin meglumine, and ketoprofen in horses. J. Am. Vet. Med. Assoc. 202, 71-77

Millet S., Kumar S., De Boever J., Meyns T., Aluwé M., De Brabander D., Ducatelle R. (2012) Effect of particle size distribution and dietary crude fibre content on growth performance and gastric mucosa integrity of growing-finishing pigs. Vet. J. 192, 316-321

Mößeler A., Köttendorf S., Große Liesner V., Kamphues J. (2010) Impact of diets' physical form (particle size; meal/pelleted) on the milieu within the stomach content (dry matter content, $\mathrm{pH}$, chloride concentration) of pigs. Livestock Sci. 134, 146-148

Mößeler A., Wintermann M., Sander S. J., Kamphues J. (2012) Effect of grinding and pelleting fed either dry or liquid feed on dry matter and $\mathrm{pH}$ in the stomach of pigs and the development of gastric ulcers. Anim. Sci. 90, 343-345 
Murray M. J. (1997) Suppression of gastric acidity in horses. J. Am. Vet. Med. Assoc. 21 1, 37-40

Murray M. J. (1999) Pathophysiology of peptic disorders in foals and horses: a review. Equine Vet. J. Supplements 29, 14-18

Nadeau J. A., Andrews F. M., Mathew A. G., Argenzio R. A., Blackford J. T., Sohtell M., Saxton A. M. (2000) Evaluation of diet as a cause of gastric ulcers in horses. Am. J. Vet. Res. 61, 784-790

Naumann C., Bassler R. (1976) Methoden der landwirtschaftlichen Forschungs- und Untersuchungsanstalt Biochemische Untersuchung von Futtermitteln. Methodenbuch III (mit Ergänzungslieferungen bis 2004). Verlag VDLUFA, Darmstadt

Sykes B. W., Hewetson M., Hepburn R. J., Luthersson N., Tamzali Y. (2015) European College of Equine Internal Medicine-Consensus statement: Equine Gastric Ulcer Syndrome (EGUS) in adult horses. Vet. Int. Med. 29, 1288-1299

Szabo S., Kato K., Pinkus G. S., Morales R. E., Vattay P., Folkman J. (1994) Accelerated healing of duodenal ulcers by oral administration of a mutein of basic fibroblast growth factor in rats. Gastroenterol. 106, 1106-1111

van Soest P. J., Robertson J. B., Lewis B. A. (1991) Methods for dietary fiber, neutral detergent fiber, and nonstarch polysaccharides in relation to animal nutrition. Dairy Sc. 74, 3583-3597

Vondran S., Venner M., Vervuert I. (2016) Effects of two alfalfa preparations with different particle sizes (alfalfa chaff vs alfalfa pellets) on the gastric mucosa in weanlings. BMC Vet. Res. 12, $110-$ 118 